\title{
GERMINATION OF CHIA SEEDS IN DIFFERENT SUBSTRATES AND WATER VOLUMES $^{1}$
}

\author{
EMANOELA PEREIRA DE PAIVA ${ }^{2 *}$, SALVADOR BARROS TORRES ${ }^{2}$, JÉSSICA REGIANE DE OLIVEIRA \\ MORAIS $^{2}$, FRANCISCO VANIES DA SILVA SÁ ${ }^{2}$, MOADIR DE SOUSA LEITE ${ }^{2}$
}

\begin{abstract}
Water availability and substrate type are essential factors in seed germination tests, influencing imbibition and seedling development. The objective of this study was to evaluate the influence of two substrates and different water volumes on the germination and vigor of chia seeds. The experimental design was completely randomized in a $2 \times 6$ factorial scheme, which consisted of two substrates, paper towel $\left(\right.$ Germitest $\left.^{\circledR}\right)$ and blotting paper, soaked with six water volumes equivalent to $1.5,2.0,2.5,3.0,3.5$, and 4.0 times their dry weight, in four replicates of 50 seeds each. Germination percentage, mean time of germination, shoot length, radicle length, shoot dry matter, radicle dry matter, total dry matter (seedling), and root/shoot ratio were evaluated. Based on our results, germination tests for seeds of chia should be conducted using blotting paper (on paper) as substrate, with a water volume of 2.5 to 4.0 times its dry weight. Chia seedlings grown on blotting paper showed greater growth and dry matter accumulation compared to those grown on paper towel.
\end{abstract}

Keywords: Lamiaceae. Salvia hispanica. Seed analysis. Seedling growth. Water availability.

\section{GERMINAÇÃO DE SEMENTES DE CHIA EM DIFERENTES SUBSTRATOS E VOLUMES DE ÁGUA}

RESUMO - A disponibilidade de água e o tipo de substrato são requisitos essenciais para a condução do teste de germinação em sementes, por influenciarem na embebição e no desenvolvimento das plântulas. Objetivou-se avaliar a influência de dois substratos e diferentes volumes de água sob a germinação e vigor de sementes de chia. O delineamento experimental foi o inteiramente casualizado, em esquema fatorial $2 \times 6$, sendo dois substratos substratos de papel toalha $\left(\right.$ Germitest $\left.^{\circledR}\right)$ e mata-borrão umedecidos com seis volumes de água equivalentes a 1,$5 ; 2,0 ; 2,5 ; 3,0 ; 3,5$ e 4,0 vezes o seu peso seco, em quatro repetições de 50 sementes. Avaliouse a percentagem e o tempo médio de germinação, comprimento da parte aérea e da radícula, massa seca da parte aérea, radícula e total (plântula) e a relação raiz/parte aérea. O teste de germinação de sementes de chia deve ser conduzido no substrato mata-borrão (sobre papel) com quantidade de água entre 2,5 a 4,0 vezes o peso do papel seco. As plântulas de chia oriundas do papel mata-borrão obtiveram maior crescimento e acúmulo de matéria seca em relação às do papel toalha.

Palavras-chave: Lamiaceae. Salvia hispanica. Análise de sementes. Crescimento de plântulas. Disponibilidade hídrica.

\footnotetext{
*Corresponding author

${ }^{1}$ Received for publication in $04 / 05 / 2018$; accepted in $11 / 19 / 2018$

Paper extracted from the doctoral thesis of the first author.

${ }^{2}$ Center of Agricultural Sciences, Universidade Federal Rural do Semi-Árido, Mossoró, RN, Brazil; emanuelappaiva@hotmail.com ORCID: 0000-0003-4510-9205, sbtorres@ufersa.edu.br - ORCID: 0000-0003-0668-3327, jessica rgn@hotmail.com - ORCID: 0000-00015353-0871, vanies_agronomia@hotmail.com - ORCID: 0000-0001-6585-8161, moadir@outlook.com - ORCID: 0000-0003-0432-0522.
} 


\section{INTRODUCTION}

Salvia hispanica L., known as chia, is a herb species belonging to the Lamiaceae family. Its seeds contain high levels of essential fatty acids, potent antioxidants, proteins, dietary fiber, and important phenolic compounds that act as natural antioxidants, having anti-inflammatory, antithrombotic, and antitumor properties (ALI et al., 2012; BUENO et al., 2010; JEONG et al., 2010). However, despite the economic and dietary importance of this species, there are still few studies on its agronomic aspects, especially in regard to seed technology.

Thus, determining the appropriate conditions for the germination of seeds of a certain species is important due to the divergence of responses that may occur under the influence of several factors, such as dormancy, substrate, water volume, light, temperature, and oxygen. In addition, in seed analysis, knowledge on the ideal conditions for germination is extremely important for the standardization of tests in different laboratories, avoiding discrepancies between results (CARVALHO; NAKAGAWA, 2012; MARCOS FILHO, 2015).

Among the factors affecting seed germination, substrate and water availability stand out because of their direct influence. In the germination test, an appropriate substrate must be used to provide sufficient amounts of water for soaking the seeds, besides serving as a support for germinated seedlings (SCHMIDT, 2007). Thus, the choice of the substrate type should take into account the size of the seed, its requirement in terms of water, light sensitivity, and substrate for the development and evaluation of seedlings (BRASIL, 2009).

Besides the substrate, the amount of water available should follow the standards described in the Rules for Seed Analysis (RAS) (BRASIL, 2009); substrates based on paper are soaked according to the relationship between water volume and dry weight. Water volumes ranging between 2.0 and 3.0 times the substrate weight are recommended, regardless of the species. However, Azeredo et al. (2010), using seeds of Brassica oleracea, and Jacinto, Benett and Benett (2014), using seeds of Glycine max, observed satisfactory percentages of germination with water volumes of 3.5 and 4.0 times the weight of the paper.

The standardization of the water volume in the substrate which favors germination, according to the species, probably contributes to minimizing variations in test results. Because the recommendations of the RAS do not apply to all species, studies adjusting the actual germination responses according to the water volumes are required (AMARO et al., 2014). Generally, excess moisture in the substrate reduces germination, compromising respiration and hindering the entire metabolic process, thereby leading to a reduction in viability, besides contributing to the proliferation of pathogenic agents (PACHECO et al., 2007). On the other hand, water deficit precludes the resumption of embryonic axis growth, hindering the sequence of biochemical, physical, and physiological processes required to trigger germination (FLORES et al., 2013).

In this context, we evaluated the influence of two substrates and different water volumes on the germination and vigor of chia seeds.

\section{MATERIAL AND METHODS}

The experiment was conducted using chia seeds with an initial moisture content of $6.8 \%$, purchased from the producers of Santana do

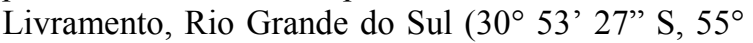
31 ' 58" W; $208 \mathrm{~m}$ above sea level). Upon reception, the seeds were homogenized, placed in plastic bags, and stored in a cold chamber $\left(10^{\circ} \mathrm{C}\right.$ and $50 \%$ relative humidity) until the experiment was conducted.

The substrates consisting of paper towel $\left(\right.$ Germitest $^{\circledR}$ ) and blotting paper were initially soaked with six water volumes equivalent to $1.5,2.0,2.5$, $3.0,3.5$, and 4.0 times their dry weight. The paper towel was arranged in the form of a roll (three sheets) and soaked with the respective water volumes, whereas for the blotting paper, two sheets were used and seeds were sown on the substrate, which was subsequently placed in Gerbox-type transparent plastic boxes $(11 \times 11 \times 3.5 \mathrm{~cm})$. After soaking the substrates, the paper roll and plastic boxes were placed in 0.04-mm-thick transparent plastic bags to avoid water loss through evaporation. Subsequently, they were placed in a Biochemical Oxygen Demand (BOD) germination chamber under an 8-h photoperiod, without additional water.

After sowing, germination was monitored for 8 days, considering as normal seedlings those which produced primary roots and seedling shoots (BRASIL, 2009), and the results were expressed in percentages. Mean time of germination was determined by daily counts; at the same time, along the period of the germination test, we counted the germinated seeds which met the same standards of normality as in the germination test. Mean time of germination was calculated using the equation proposed by Schuab et al. (2006), according to the following expression:

$\mathrm{t}=\left(\left(\sum\right.\right.$ niti $\left.)\right) /\left(\sum\right.$ ni $)$,

Eq. 01

where $\mathrm{t}=$ mean time of germination, $\mathrm{ni}=$ number of germinated seeds per day, $\mathrm{ti}=$ time of germination (days).

At the end of the germination test, normal seedlings were evaluated for growth by measuring shoot length (from collar to apex) and primary root length (from collar base to root tip), using a ruler 
graduated in centimeters. After the measurements, the shoots were separated from the roots, placed in Kraft paper bags, and dried in a forced-air circulation oven at $65^{\circ} \mathrm{C}$ until constant weight. Subsequently, the samples were weighed on an analytical scale $(0.0001$ g) to obtain shoot dry matter and root dry matter. These data were used to determine the root/shoot ratio based on the biomass accumulation in the root system relative to the shoots of the seedlings.

The experimental design adopted was completely randomized in a 2 x 6 factorial arrangement, which consisted of two types of substrate (Germitest ${ }^{\circledR}$ paper towel and blotting paper) and six water volumes $(1.5,2.0,2.5,3.0,3.5$, and 4.0 times the paper dry weight), with four replicates of 50 seeds each. The data were subjected to analysis of variance using the $\mathrm{F}$ test. According to the significance, the means were compared by Tukey's

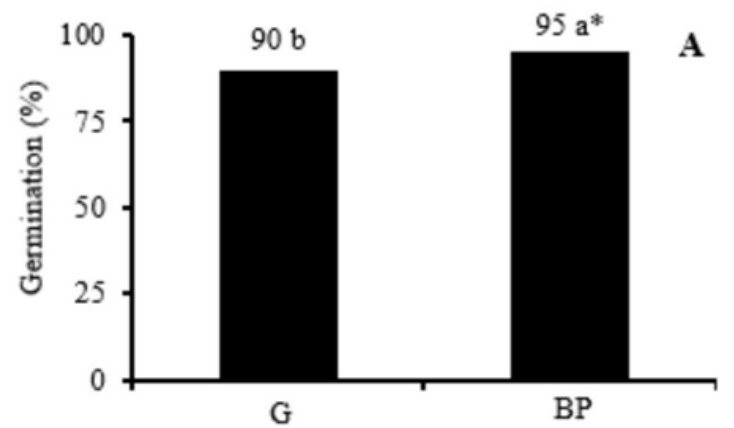

Figure 1. Germination (A) and mean time of germination, MTG (B) for chia seeds germinated on the substrates paper towel $\left(\right.$ Germitest $\left.^{\circledR}\right)(\mathrm{G})$ and blotting paper $(\mathrm{BP})$.

The substrate soaking levels did not influence the germination percentages and the mean time of germination of chia seeds, irrespective of the substrate (Figure. 1A and B). Studies on the influence of the water volume in the substrate during the germination process are of high importance since the speed of hydration indicates shows that this factor is linked to water availability, substrate matric potential, temperature, and intrinsic characteristics of the seed (VARELA; RAMOS; MELO, 2005).

The epicarp of $S$. hispanica seeds contains cells that produce mucilage when moistened. When contact with water, the epicarp swells, the cuticle breaks as its elasticity is exceeded, and the cell contents come out as mucilage, surrounding the entire fruit surface (IXTAINA et al., 2011). Capitani et al. (2012) state that the fibrous fractions of this species have a great capacity to retain and absorb water, making it important to use adequate volumes of water to conduct germination tests; if the water volume is too low for seed soaking and mucilage formation, germination is compromised. Thus, the test and subjected to polynomial regression analysis $(\mathrm{p} \leq 0.05)$, using the statistical program SISVAR $^{\circledR}$ (FERREIRA, 2011)

\section{RESULTS AND DISCUSSION}

Germination percentage and mean time of germination were influenced by the substrates, and seeds germinated on blotting paper had higher percentages of germination in a shorter time compared to those on the paper towel (Germitest ${ }^{\mathbb{R}}$ ), suggesting that blotting paper was more appropriate for the germination of chia seeds (Figure. 1A and B). Similar results have been reported by Azeredo et al. (2010), who observed that blotting paper as substrate favored the germination of cabbage seeds in comparison with paper towel.

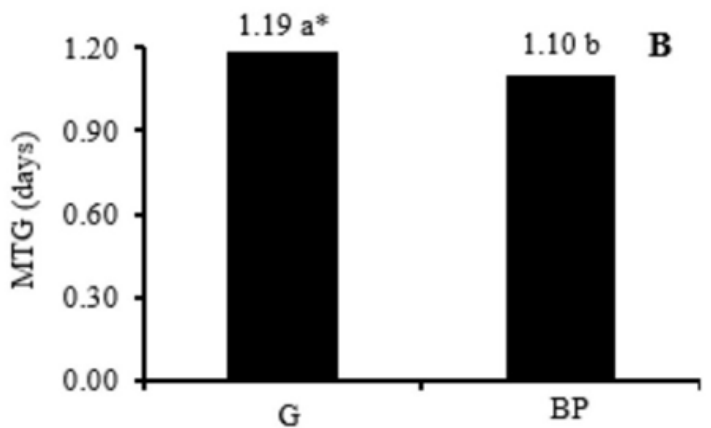

soaking ranges used in this study were satisfactory for the formation and extrusion of mucilage and allowed the production of roots.

A significant influence of the interaction between substrates and water volumes was observed for shoot length, radicle length, shoot dry matter, radicle dry matter, total dry matter (seedling), and root/shoot ratio (Figure. 2A, B, C, D, E, and F). As previously mentioned, water volume had a significant effect on all growth variables evaluated. During the germination process, water absorption causes softening of the coat and increases in the volume of the embryo and the reserve tissues, favoring coat rupture, gas diffusion, and primary root emergence. It also promotes dilution of the protoplasm, allowing the diffusion of hormones and, consequently, the activation of enzymatic systems. This leads to the digestion, translocation, and assimilation of reserves, resulting in embryo growth (MARCOS FILHO, 2015), with also affects seedling performance. 

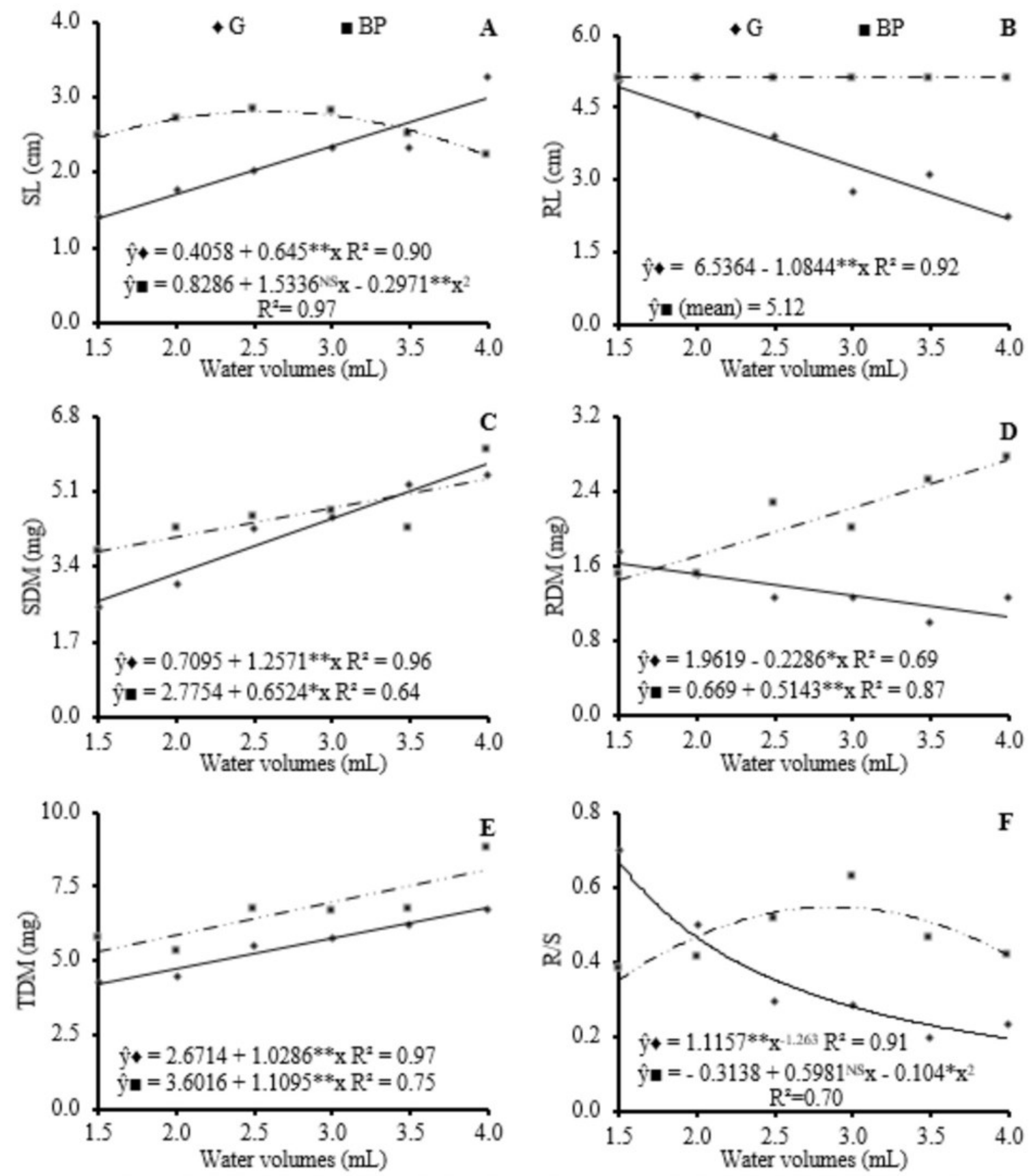

$\mathrm{NS}, * *$ and $*=$ not significant, significant at 0.01 and $0.05(\mathrm{p}<0.01$ and $\mathrm{p}<0.05)$, respectively.

Figure 2. Shoot length, SL (A), radicle length, RL (B), shoot dry matter, SDM (C), radicle dry matter, RDM (D), total dry matter, TDM (E), and root/shoot ratio, R/S (F) of chia seedlings germinated on paper towel (Germitest $\left.{ }^{\mathbb{B}}\right)(\mathrm{G})$ and blotting paper (BP) under different water volumes.

For shoot length and radicle length of seedlings germinated on paper towel, we noted that shoot length increased by $0.65 \mathrm{~cm}$ for every unit increase in water volume, whereas the radicle responded inversely, reducing its growth by $1.08 \mathrm{~cm}$ per unit increase in water volume (Figure. $2 \mathrm{~A}$ and $\mathrm{B})$. The reduction in radicle growth as a function of water availability is due to the absence of a water deficit. Thus, there is no stimulus for the development of the root system in search for favorable conditions (water availability). In addition, such reduction did not hamper shoot development in seedlings grown on paper towel, which indicates the absence of stress. Reductions in radicle growth and increase in shoot length have also been observed by Amaro et al. (2014) in seeds of Cucumis melo L., by Araújo et al. (2014) in seeds of Luffa operculata (L.) Cogn., and by Martins, Bovi and Spiering (2009) in seeds of Bactris gasipaes.

In relation to the blotting paper, there was a 
quadratic behavior of shoot length, with the greatest length $(2.81 \mathrm{~cm})$ under the estimated water volume of 2.6 times the paper weight, with a progressive reduction of growth at higher soaking levels. However, there was no significant effect on radicle length, with a mean value of $5.12 \mathrm{~cm}$ (Figure. 2A and B). The reduction of shoot growth in seedlings germinated on blotting paper may be related to the lower availability of oxygen, because in this substrate, there are greater limitations of space compared to the paper towel, facilitating the soaking.

An increasing linear behavior for shoot dry matter accumulation in $S$. hispanica seedlings was observed in both substrates; in seedlings cultivated at the highest soaking level (4.0 times the substrate volume), growth was 2.22 and 1.44 times greater than that of seedlings under the lowest soaking level (1.5 times the substrate volume) for the substrates paper towel and blotting paper, respectively (Figure. 2C).

In terms of root dry matter accumulation in $S$. hispanica seedlings, we observed an increasing linear behavior as a function of water volume. For blotting paper, there was an increase of $89.6 \%$ in the dry matter accumulation of seedlings cultivated at the highest soaking level compared to the lowest level. However, for the paper towel, there was a decreasing linear behavior, with a reduction of $11.72 \%$ for every unit increase of water volume in the substrate (Figure. 2D). For the blotting paper, which has a lower weight and volume compared to the paper towel, the increase in water availability was beneficial, indicating inadequate water availability at the lowest soaking levels, 1.5 and 2.0 times the paper weight. However, for the paper towel, whose weight and volume were five times higher than those of the blotting paper, water addition led to lower biomass accumulation in the roots. Nevertheless, since there was no restriction in shoot development, water availability was satisfactory at all levels studied, and plants will invest more in shoot development (Figure. 2C and D).

For the total dry matter accumulation of $S$. hispanica seedlings, an increasing linear behavior was observed for both substrates. Seedlings cultivated at the highest soaking level (4.0 times the substrate volume) showed superior growth, 61.28 and $53.14 \mathrm{~cm}$, compared to those at the lowest soaking level (1.5 times the substrate volume) for the substrates paper towel and blotting paper, respectively (Figure. 2C). According to Taiz and Zeiger (2013), in water deficit situations, the metabolic processes of the seedlings are changed, and cell elongation and differentiation are responses of plant tissues to the amount of water available in the substrate, a fact confirmed by the lower phytomass accumulation observed in seedlings germinated under the lowest water volumes in the substrate.
Seeds germinated on paper towel showed lower gains in total dry matter accumulation compared to those germinated on blotting paper (Figure. 2E). This fact may be related to the greater volume of water available in the paper towel due to its larger area and, consequently, higher weight compared to the blotting paper. An effect of water availability on the gain of seedling dry matter has also been observed by Almeida and Rocha (2002) for seeds of Brassica oleracea (L.) Mill. and by Lopes and Macedo (2008) for seeds of Brassica pekinensis (Lour.) Rupr.

For the root/shoot ratio of $S$. hispanica seedlings, a quadratic behavior was observed in those germinated on the blotting paper, and the highest value (0.55) was found under an estimated volume of 2.9 times the paper weight, with a subsequent reduction in the root/shoot ratio (Figure. $2 \mathrm{~F}$ ). These results indicate that up to a water volume of 2.9 times the paper weight, there was a greater investment in radicle development than in shoot development, possibly due to the lower availability of water in the substrate. However, as water availability increased, shoot development stood out compared to the root system.

For the paper towel, there was a potential reduction in the root/shoot ratio of $S$. hispanica seedlings, indicating that those established under this condition had greater shoot growth compared to the growth of the root system, corroborating the results of root dry matter, a fact related to the higher availability of water, as previously mentioned (Figure. 2F). The obtained results indicate that, under favorable water availability, the seedling tends to invest more in shoot growth than in root growth. An increase in water availability, associated with gain in seedling dry matter, has also been observed by Pereira, Santos and Medeiros Filho (2011), who worked with seeds of Solanum sessiliflorum Dunal.

\section{CONCLUSIONS}

Germination tests for seeds of chia should be conducted using blotting paper (on paper) as substrate, with a water volume of 2.5 to 4.0 times its dry weight.

Chia seedlings grown on blotting paper showed greater growth and dry matter accumulation compared to those grown on paper towel.

\section{REFERENCES}

ALI, N. M. et. al. The promising future of chia, Salvia hispanica L. Journal of Biomedicine and Biotechnology, v. 2012, n. 1, p. 1-9, 2012.

ALMEIDA, C. A.; ROCHA, S. C. S. Fluidodinâmica 
de sementes de brócolos. Scientia Agrícola, v. 59, n. 4, p. 645-652, 2002.

AMARO, H. T. R. et. al. Umedecimento do substrato e temperatura na germinação e vigor de sementes de melão. Semina: Ciências Agrárias, v. 35, n. 3, p. 1119-1130, 2014

ARAÚJO, P. C. et. al. Different water volumes in the substrate and temperatures for germination of cabacinha seeds. Horticultura Brasileira, v. 32, n. 3, p. 367-370, 2014.

AZEREDO, G. A. et. al. Umedecimento e substratos para germinação de sementes de repolho. Pesquisa Agropecuária Tropical, v. 40, n. 1, p. 77-82, 2010.

BRASIL. Ministério da Agricultura, Pecuária e Abastecimento. Regras para Análise de Sementes. Ministério da Agricultura, Pecuária e Abastecimento. Secretaria de Defesa Agropecuária. Brasília, DF: MAPA/ACS, 2009. 395 p.

BUENO, M. et. al. Análisis de la calidad de los frutos de Salvia hispanica L. (Lamiaceae) comercializados en la ciudad de Rosario (Santa Fe, Argentina). Boletin Latinoamericano y del Caribe de Plantas Medicinales y Aromaticas, Santiago, v. 9, n. 3, p. 221-227, 2010.

CAPITANI, M. I. et. al. Physicochemical and functional characterization of by-products from chia (Salvia hispanica L.) seeds of Argentina. LWT Food Science and Technology, v. 45, n. 1, p. 94102, 2012.

CARVAlho, N. M.; NAKAGAWA, J. Sementes: ciência, tecnologia e produção. 5. ed. Jaboticabal, SP: FUNEP, 2012. 590 p.

FERREIRA, D. F. Sisvar: A computer statistical analysis system. Ciência e Agrotecnologia, v. 35, n. 6, p. 1039-1042, 2011.

FLORES, A. V. et. al. Umedecimento do substrato e temperatura na germinação de sementes de Melanoxylon brauna Schott. Revista Brasileira de Ciências Agrárias, v. 8, n. 3, p. 454-457, 2013.

IXTAINA, V. Y. et. al. Characterization of chia seed oils obtained by pressing and solvent extraction. Journal of Food Composition and Analysis, v. 24, n. 2, p. 166-174, 2011.

JACINTO, J. T. D.; BENETT, K. S. S.; BENETT, C. G. S. Influência do substrato e do teor de água sobre a germinação de sementes de soja. Revista de Agricultura Neotropical, v. 1, n. 1, p. 97-102, 2014.
JEONG, S. K. et. al. Effectiveness of tropical chia seed oil on pruritus of end-stage renal disease (ESRD) patients and healthy volunteers. Annals of Dermatology, v. 22, n. 2, p. 143-148, 2010.

LOPES, J. C; MACEDO, C. M. P. Germinação de sementes de couve chinesa sob influência do teor de água, substrato e estresse salino. Revista Brasileira de Sementes, v. 30, n. 3, p. 79-85, 2008.

MARCOS FILHO, J. Fisiologia de sementes de plantas cultivadas. 2. ed. Londrina, PR: ABRATES, 2015. $660 \mathrm{p}$.

MARTINS, C. C.; BOVI, M. L. A.; SPIERING, S. $H$. Umedecimento do substrato na emergência e vigor de plântulas de pupunheira. Revista Brasileira de Fruticultura, v. 31, n. 1, p. 224-230, 2009.

PACHECO, M. V. et. al. Germinação de sementes de Apeiba tibourbou em função de diferentes substratos e temperaturas. Scientia Forestalis, v. 73 n. 1, p. 19-25, 2007.

PEREIRA, M. D.; SANTOS, C. E. M.; MEDEIROS FILHO, S. M. Germinação de sementes de cubiu (Solanum sessiliflorum Dunal). Revista Brasileira de Ciências Agrárias, v. 6, n. 1, p. 79-84, 2011.

SCHMIDT, L. Tropical forest seed. New York: Springer, 2007. 409 p.

SCHUAB, S. R. P. et. al. Potencial fisiológico de sementes de soja e sua relação com a emergência das plântulas em campo. Acta Scientiarum. Agronomy, v. 28, n. 4 , p. $553-561,2006$.

TAIZ, L.; ZEIGER, E. Fisiologia vegetal. 5. ed. Porto Alegre, RS: Artmed, 2013.918 p.

VARELA, V. P.; RAMOS, M. B. P.; MELO, M. F. F. Umedecimento do substrato e temperatura na germinação de sementes de angelim-pedra (Dinizia excelsa Ducke). Revista Brasileira de Sementes, v. 27 , n. 2, p. 130-145, 2005 